\title{
Gender disparities in colorectal polyps
}

\author{
A. K. Safiyeva \\ Central Customs Hospital, Baku, Azerbaijan Republic

\section{Гендерные различия колоректальных полипов}

\author{
А. К. Сафиева
}

Центральный таможенный госпиталь, г. Баку, Азербайджанская Республика

\begin{abstract}
Objective. The main objective of the research is the pathohistological consequences of colorectal adenomatosis polyps and their gender-based assessment. Gender and its connection with advanced colorectal displasia are the focus of the research study. Materials and methods. A retrospective analysis was conducted 100 patients. The age group of the patients in the research study mainly encompassed 19 to 65 aged patients. During the medical procedure, the gender distribution of the cases was determined as 60 males and 40 females respectively.

Results. There is strong evidence for an association between gender and the risk of advanced colorectal neoplasia. The findings regarding the positive interrelation for gender and advanced colorectal neoplasia are consistent with other large colonoscopy-based studies.

Conclusions. As a result of the study, we would like to emphasize that colorectal polyps are more common in men compared to in women.

Keywords: gender disparities; colorectal polyps; colorectal cancer; colonoscopy; neoplasm.

Реферат

Цель. Изучить гендерные характеристики, связанные с колоректальной дисплазией. Имеются убедительные доказательство того, что риск развития колоректальной неоплазии связан с половыми различиями, но этиология этого различия остается неясной. Это может быть вызвано как гормональным фоном, так и генетическими особенностями женщин и мужчин.

Материалы и методы. Ретроспективный анализ был проведен группе 100 пациентов. В исследование в основном включаены пациенты в возрасте от 19 до 65 лет, среди нихбыло 60 мужчин и 40 женщин.

Результаты. Результаты относительно положительной взаимосвязи женского пола и распространенности колоректальной неоплазии, основаны на колоноскопии и других клинико-лабораторных расширенных исследованиях.

Выводы. В результате исследования мы хотели бы подчеркнуть, что колоректальные полипы чаще встречаются у мужчин, чем у женщин.

ключевые слова: гендерные различия; колоректальные полипы; колоректальный рак; колоноскопия; неоплазия.
\end{abstract}

Colorectal adenomas are more commonly found in the developed Western states. In this regard, nutritional factor, environment, inflammatory diseases of the gastrointestinal tract, ulcerative colitis, and "Crohn's disease" demonstrates an important role in the formation of colorectal polyps [1]. Thus, the reduction of proliferation and apoptosis in colon cells increases the risk of carcinogenesis under the background of inflammatory diseases. According to this, polyps less than $1 \mathrm{~cm}$ in size constitute $1 \%$ likelihood to be malignant, slightly greater than $1 \mathrm{~cm}$, around 1 to $2 \mathrm{~cm}$ of those have a $10 \%$ chance of becoming cancer, but those are $2 \mathrm{~cm}$ or greater have a $40 \%$ chance of transforming into malignancy. Whilst, polyps less than $1 \mathrm{~cm}$ and 1 to $2 \mathrm{~cm}$ have a $10 \%$ probabilityin villous adenomas, and more than $2 \mathrm{~cm}$ have a 53\% chance of turning into malignancy. Therefore, these derivatives can be repeated and the risk of transition to the neoplastic process can be variable depending mainly on their characteristics including multiplicity, dimen- sions, histological structure, and dysplasia. It has been considered that $15 \%$ of all derivatives with a size of more than $1 \mathrm{~cm}$ are likely to be transmitted to malignant neoplasms within 10 years [2 - 4].

Generally, the colon polyps are more founded pathology and commonly are observed in over 50 aged patients group. Colorectal polyps are not only malignant pathology but also the precursor of malignant neoplasms. Where the polyps are mostly detected, there is a high likelihood of being cancer, which normally grows in around 5\% of adenomatous polyps [5]. It is an overt fact that based on studies, the colorectal adenomas are mainly accompanied by epithelial dysplasia, which is considered the main cause of malignant neoplasms, are "sneak" lesions of colon (intestinal) cancer, playing a major role in the spread of colorectal polyps and the formation of malignant neoplasms. In this matter, adenomatous polyps are the significantly important cause of colorectal cancer $[1,3,6,7]$. 
The dysplasia can also be observed in colorectal adenomas showing that it is the predecessor of malignant tumors. According to this, the development of colorectal adenomas in the colon is also the main insignia of malignant tumor progression. The number of polyps, histological structure, and grade of dysplasia is essential amid the transition into malignancy. Besides, the complex glandular crowding and irregularity, prominent glandular budding, cribriform structures, vague luminal papillary extensions, and back-to-back glands were observed in the analysis. The colon cancers encompass $30 \%$ to $50 \%$ of adenomas $[2,8,9]$. The formation of ectopic crypts leads to dysplasia. Abnormal differentiation of crypts in basal layer cause the development of colorectal cancer $[3,9,10]$.

It is ostensibly that thestrong evidence for an association between gender and the risk of advanced colorectal neoplasia emerged out. The findings of a positive association for gender and advanced colorectal neoplasia are consistent with other large colonoscopy-based studies. The etiology for the gender difference remains uncertain, but it might be related to hormonal differences.Genetic differences between men and women might account for some of the differences in the rate of advanced neoplasia [11].

Aim of study. The pathohistological consequences of colorectal adenomatosis polyps andtheir gender based assessment were considered objective of the chosen research.

\section{Materials and methods}

Between the period of 2011 and 2016, the endoscopic polypectomy was performed in 118 out of 1375 patients enrolled at the Endoscopy Department of the Central Customs Hospital in Baku, Azerbaijan. The polypectomy was performed with a squeezing ring and a biopsy clamp. A retrospective analysis was conducted in 100 of these patients. The age group of the patients in the research study mainly encompassed 19 to 65 aged patients. During the examina-

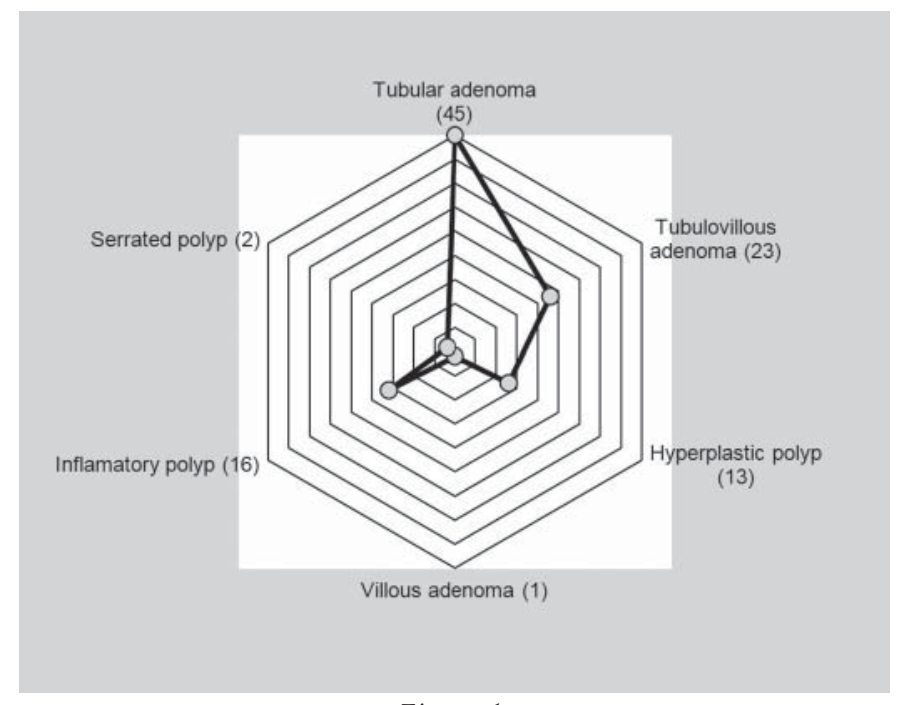

Histopathologic distribution of polyps. tion, 18 patients were excluded from the study group for certain reasons. The colonoscopic examination was performed in patients above 45 years of age who had gastrointestinal disorders, bleeding, bloody mucous, and constipation. The patients underwent bowel preparation and those with cardiac problems were referred to the cardiologist before the medical procedure that was conducted. Colonoscopy was performed under intravenous sedation, and the patients were discharged to their homes right after the medical procedure.

\section{Results}

The retrospective study included 100 parafin blocks of polypectomized specimens. During the medical procedure, those blocks were used to examine 100 polyps based on gender disparities. Tissue preparation was done in Central Customs Hospital Patomorphology Department. The sections were taken from the paraffin-embedded tissues using a microtome, afterward, put on the slide, and stained with hematoxylin eosin (HE). Because of the investigation, it was revealed out that colorectal polyps are more common in men than in women.

In line with the histological examination of Hematoxylin and Eosin stained (H\&E) preparations, there were 45 tubes, 23 tubulovillous, 16 inflammatory, 13 hyperplastic, 2 serrated and one polyp in the villous form were detected. The middle age of the patients was $56.78 \pm 1.64$. In this study, around 38 patients constituted 50 to 69 age group and 5 patients were included between 40 and 49 age group. Generally, the proportion of the detection of colorectal adenomas in men and women is about 1.5:1.

In terms of localization of colorectal adenomas, the distal region of the colon was superior to the proximal region. The average size of the colorectal adenomas was $1.27 \mathrm{~cm} \pm$ 0.11 , which ranged from 0.3 to $3.2 \mathrm{~cm}$ and the average size of the villous adenomas was $1.14 \mathrm{~cm}$. The size of the tubular adenomas ranges from 0.8 to $3 \mathrm{~cm}$ with an average of $1.38 \mathrm{~cm}$. Tubulovillous adenomas range from 0.3 to $3.2 \mathrm{~cm}$, with an average of $1.4 \mathrm{~cm}$. When the cases were inspected in terms of having or not having dysplasia, it was detected that dysplasia was present in 42 cases and was absent in 58 cases. When 42 cases with dysplasia were followed, 26 cases constituting $61.9 \%$ of it proceeded to the malignancy over time. 16 cases estimating $38.1 \%$ did not develop the malignancy. Malignancy of the polyps with high and low dysplasia is far more expected. Dysplasia has been detected in large dimensional polyps, which overlaps with the literature data. In this manner, in the chosen study, there is $32.5 \%$ of dysplasia in polyps less than $1 \mathrm{~cm}$, and polyps 1 to $3 \mathrm{~cm}$ have $70.58 \%$ of dysplasia, and $100 \%$ of it, is observed in $3 \mathrm{~cm}$ large polyps. Dysplasia was detected 26 out (32.5\%) of 80 patients, which have smaller polyps of $1 \mathrm{~cm}$. We found dysplasia in 12 out of 17 polyps (70.58\%) between 1 to $3 \mathrm{~cm}$ in size, while dysplasia was found in all 3 polyps (100\%) larger than $3 \mathrm{~cm}$. 

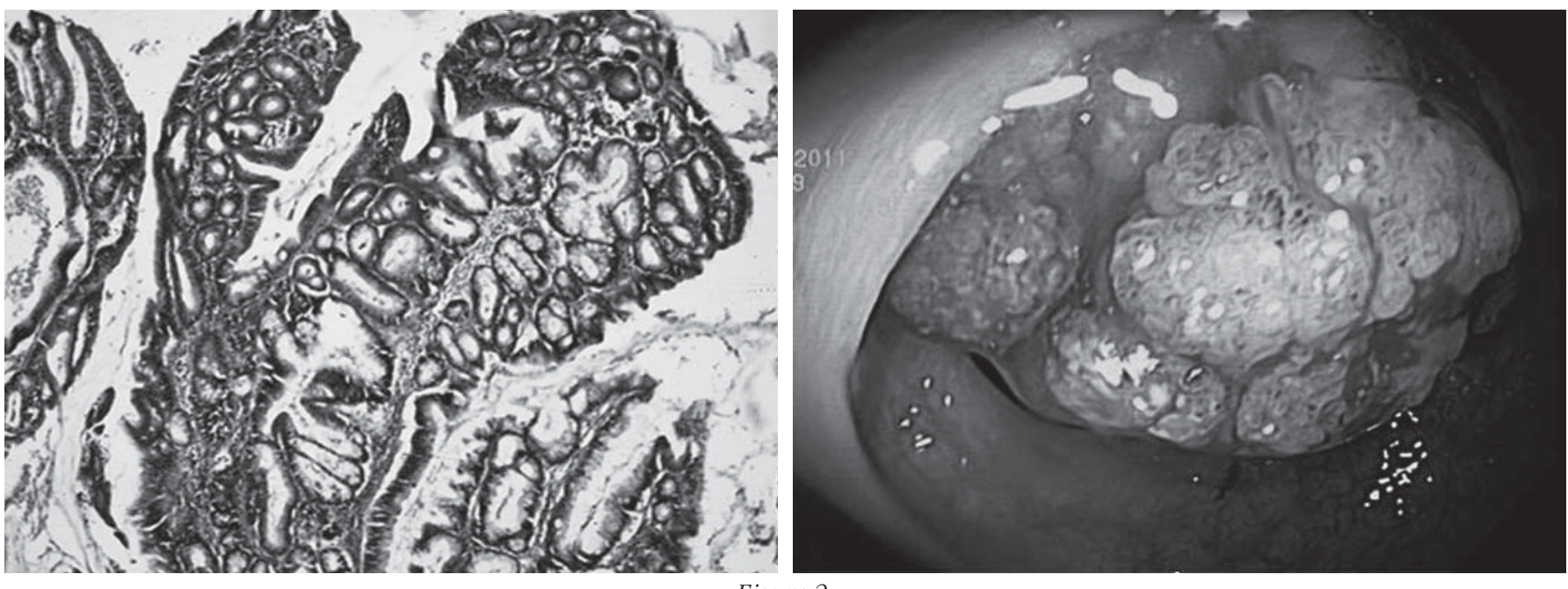

Giant villous polyps and its bistological structure.

\section{Discussion}

The medical examination was conducted with the evaluation of bowel and the detected polyps were treated mainly depending on their sizes. Amid the procedure, small polyps removed by forceps biopsy, and $0.5 \mathrm{~cm}$ large polyps have been cut off by squeezing ring. All detected polyps were sent to the pathological examination. During the medical procedure, the gender distribution of the cases was determined as 60 males and 40 females respectively. As a result of the examination, the pathophysiological classification is identified as followed. Histopathological evaluation revealed tubular adenoma in 46 cases, (18 females and 28 males) tubulovillous adenoma in 23 cases ( 7 females and 16 males) inflammatory polyp in 15 cases, ( 8 females and 7 males) hyperplastic polyp in 13 cases, ( 4 females and 9 males) serrated polyp in 2 cases, ( 1 female and 1 male) and villous adenoma in one ( 1 female) case. In the cases we examined, we found several polyps ranging from 1 to 3 .

Studies have shown that tubular polyps are present in both sides of the intestine, tubulovillous polyps on the left side, and villous polyps are mostly localized in the rectosigmoid region. The chosen study revealed that the size of polyps is directly correlated with their pathomorphological structures. The patients with tubular adenomatous polyps were asked to undergo the follow-up examination once a year and those with villous hyperplasia were asked to take the follow-up examination once every 6 months. Two patients with a high degree of dysplasia were surgically treated (Fig. 1).

In the study, 13 removed polyps were cosnidered hyperplastic polyps. Dysplasia of polyps was assessed pathophysiologically and was found in 42 (14 females and 28 males) cases of the 100 polyps, but the remaining 58 ( 25 females and 33 males) polyps did not show dysplasia. When revaluated 42 polyps detected in dysplasia 26 out of them (61.9\%) later developed malignancy and it was not detected in 16 patients. (38.1\%)None of the 58 polyps with dysplasia were detected in malignancy (Fig. 2).

\section{Conclusions}

As a result of the study, we would like to emphasize that colorectal polyps are more common in men compared to in women. Hence, gender and its connection with advanced colorectal displasia are the focus of the research study. During the medical procedure, the gender distribution of the cases was determined as 60 males and 40 females respectively. A progressive risk of polyp or tumor formation is noted with aging. Colonoscopy is needed to correctly diagnose an increasing prevalence of pathology in the elder people. The findings of a positive association for gender and advanced colorectal neoplasia are consistent with other large colonoscopy-based studies. The etiology for the gender difference remains uncertain, but it might be related to hormonal differences. Genetic differences between men and women might account for some of the differences in the rate of advanced neoplasia.

Funding. The chosen study was not supported or funded by any drug company. During the examination process, the research study did not receive any financial support from either institution or funding companies.

Acknowledgment. The author expresses her sincere gratitude to Central Customs Hospital the Department of Surgical Diseases for additional data collection and analysis, pathohistologic and colonoscopic examination, and other related things.

Conflict of interest. There is no conflict of interest

\section{References}

1. Yashiro M. Ulcerative colitis-associated colorectal cancer. World J Gastroenterol. 2014 Nov 28;20(44):16389-97. doi: 10.3748/wjg. v20.i44.16389. PMID: 25469007; PMCID: PMC4248182..

2. Doniec JM, Löhnert MS, Schniewind B, Bokelmann F, Kremer B, Grimm H. Endoscopic removal of large colorectal polyps: prevention of unnecessary surgery? Dis Colon Rectum. 2003 Mar;46(3):340-8. doi: 10.1007/s10350-004-6553-x. PMID: 12626909. 


\section{Киінічна хірургія}

3. Bertelson NL, Kalkbrenner KA, Merchea A, Dozois EJ, Landmann RG, De Petris G, et al. Colectomy for endoscopically unresectable polyps: how often is it cancer? Dis Colon Rectum. 2012 Nov;55(11):1111-6. doi: 10.1097/DCR.0b013e3182695115. PMID: 23044670.

4. Amato A, Radaelli F, Dinelli M, Crosta C, Cengia G, Beretta P, et al. Early and delayed complications of polypectomy in a community setting: The SPoC prospective multicentre trial. Dig Liver Dis. 2016 Jan;48(1):43-8. doi: 10.1016/j.dld.2015.09.007. Epub 2015 Sep 28. PMID: 26493629.

5. Marley AR, Nan H. Epidemiology of colorectal cancer. Int J Mol Epidemiol Genet. 2016 Sep 30;7(3):105-114. PMID: 27766137; PMCID: PMC5069274.

6. Ferrand A, Sandrin MS, Shulkes A, Baldwin GS. Expression of gastrin precursors by CD133-positive colorectal cancer cells is crucial for tumour growth. Biochim Biophys Acta. 2009 Mar;1793(3):47788. doi: 10.1016/j.bbamcr.2009.01.004. Epub 2009 Jan 15. PMID: 19321126; PMCID: PMC2692632.

7. Lopez-Morra HA, Linn S, Tejada J, Ofori EA, Guzman LG, Sanivarapu S, et al. Sa1444 Does Insulin Influence the Risk of Colon Adenomas and Colorectal Cancer? a Multicenter Look At a Minority Population. Gastrointestinal Endoscopy. 2014;79:AB214.
8. Li Z. CD133: a stem cell biomarker and beyond. Exp Hematol Oncol. 2013 Jul 1;2(1):17. doi: 10.1186/2162-3619-2-17. PMID: 23815814; PMCID: PMC3701589.

9. Zhan T, Hahn F, Hielscher T, Betge J, Kähler G, Ebert MP, et al. Frequent co-occurrence of high-grade dysplasia in large flat colonic polyps ( $>20 \mathrm{~mm}$ ) and synchronous polyps. BMC Gastroenterol. 2015 Jul 10;15:82. doi: 10.1186/s12876-015-0312-4. PMID: 26160557; PMCID: PMC4498525.

10. Kim TO. Optimal Colonoscopy Surveillance Interval after Polypectomy. Clin Endosc. 2016 Jul;49(4):359-63. doi: 10.5946/ ce.2016.080. Epub 2016 Jul 29. PMID: 27484812; PMCID: PMC4977746.

11. McCashland TM, Brand R, Lyden E, de Garmo P; CORI Research Project. Gender differences in colorectal polyps and tumors. Am J Gastroenterol. 2001 Mar;96(3):882-6. doi: 10.1111/j.15720241.2001.3638 a.x. PMID: 11280569.

Received: 06.01.2021 